\title{
Dystans i pragnienie bezpośredniości: nowoczesna świadomość Bolesława Leśmiana
}

1.

Poezja Bolesława Leśmiana wyrasta z rozczarowania cywilizacją i prowadzi do odzyskania utraconej harmonii poety i świata ${ }^{\mathrm{T}}$. $\mathrm{Na}$ Weberowską diagnozę współczesnego społeczeństwa, które metafizyczny, religijny sposób odczuwania zastąpiło w pełni zracjonalizowanym porządkiem nauki i ekonomii, autor $Ł a k i$ odpowiada w swoich praktykach poetyckich, zmierzających do ponownego zaczarowania świata, jednak nie tego realnego, lecz poetyckiego, istniejącego w słowach i przez słowa. Leśmian w swojej twórczości próbuje pogodzić sprzeczności: pesymistyczną perspektywę izolacji człowieka od twórczej natury z wizją pierwotnej harmonii twórcy i świata; pragnienie bezpośredniości ze świadomą kreacją językową; mit poety jako człowieka pierwotnego $\mathrm{z}$ postnietzscheańskim doświadczeniem pustego nieba; intuicjonizm z samoświadomością. Jednocześnie zaś $\mathrm{w}$ ten poetycki oraz egzystencjalny projekt powrotu do pierwot-

${ }^{\text {I }}$ O nowoczesności tej poezji pisano już wielokrotnie. Wśród nowszych opracowań warto wskazać: Z. Łapiński, Dwaj nowocześni: Leśmian i Przyboś, „Teksty Drugie” 1994, nr 5-6, s. 86; R. Nycz, „Stowami... w śrwiat wygladam”. Bolestawa Leśmiana poezja nowoczesna, w: idem, Literatura jako trop rzeczywirstości. Poetyka epifanii w nowoczesnej literaturze polskiej, Kraków 2001; J. Zięba, Bolestawa Leśmiana śreiatopoglad nowoczesny. O eseistyce poety, Kraków 2000; P. Łopuszański, „Idacy z prawda u warg $i$ u powiek...”. Próba nowego spojrzenia na twórczość Leśmiana, „Teksty Drugie” 2002, nr 6; A. Kluba, Niezrozumiate - nienazwane - nowoczesne. Leśmian i Iwaszkiewicz - dwa modele poetyckiej niewyrażalności, w: eadem, Autoteliczność - referencyjność - nieweyrazalność. O nowoczesnej poezji polskiej (1918-1939), Wrocław 2004; A. Skrendo, Bolestaw Leśmian: „najtrwalszy ze wszystkich przywidzeń i dziwot”, w: idem, Poezja modernizmu. Interpretacje, Kraków 2005; P. Śniedziewski, „Treść, gdy w rytm się stacza”. Leśmian i symbolistyczna fascynacja rytmem, „Pamiętnik Literacki” 2006, z. 3; M.P. Markowski, Leśmian. Poezja i nicość, w: idem, Polska literatura nowoczesna. Leśmian, Schulz, Witkacy, Kraków 2007. 
ności wpisana jest świadomość jego klęski ${ }^{2}$. Choć może, zamiast o klęsce, lepiej mówić tu o nieziszczalności leżącego u jej źródeł marzenia. W poezji tej poczucie wyobcowania i braku - braku Boga, harmonii, bezpośredniości, zadomowienia - przekute zostaje bowiem w poetycką figurę pragnienia, którego nieziszczalność stanowi warunek jej istnienia.

$\mathrm{W}$ odróżnieniu od potrzeby, rodzacej się $\mathrm{z}$ poczucia bra$\mathrm{ku}$ i z chęci jego zaspokojenia, pragnienie „pragnie [...] ponad wszystkim, co mogłoby je po prostu zaspokoić" ${ }^{3}$. W takim ujęciu, proponowanym przez Emmanuela Lévinasa, natura pragnienia jest paradoksalna: to, co upragnione, nie zaspokaja go, lecz je pogłębia ${ }^{4}$. I ta właśnie podstawowa intuicja metafizyczna leży u podstaw podmiotowego istnienia bytów $\mathrm{w}$ świecie poezji Leśmiana, jest nieodzownym warunkiem ich istnienia. Większość jego bohaterów kieruje się właśnie pragnieniem, nie potrzebą (nawet bowiem chęć zaspokojenia erotycznych tęsknot podszyta jest koniec końców pragnieniem metafizycznym), jednakże żadnemu z nich nie jest dane doświadczyć poczucia pełni. Pełnia, rozumiana jako stan zaspokojenia i stabilności struktury „ja”, jest w świecie autora Dziewczyny nieosiągalna.

Poezja Leśmiana stwarza więc nadmiarowość, będącą otwarciem na nieskończoność jako doświadczenie metafizyczne. To świat bytów znajdujących się w najrozmaitszych stadiach i stanach istnienia, choć posługiwanie się trybem orzekającym w odniesieniu do twórczości kreującej sytuację ciągłego dziania się i metamorfoz jest zaledwie umownym chwytem. Byty Leśmianowskie są przeciwieństwem rzeczywistości wytworzonej przez społeczne normy i reguły. Obdarzone są jaką́s formą preświadomości. Tą podstawową formą byłoby pragnienie, którego obecność ujawnia się w poezji Leśmiana w kilku wymiarach: jest figurą metapoetycką, antropologiczno-egzystencjalną, epistemologiczną i ontologiczną.

${ }^{2}$ Najdobitniej sąd ten sformułował A. Skrendo w tekście Bolestaw Leśmian: „najtrwalszy ze wszystkich przywidzeń i dziwot”, op.cit.

3 E. Lévinas, Całość i nieskończoność. Esej o zewnętrzności, przeł. M. Kowalska, wstęp B. Skarga, przekład przejrzał J. Migasiński, Warszawa 1998, s. 19.

4 Lévinas posługuje się kategorią pragnienia w odniesieniu do Boga - to On jest bowiem tym, co Upragnione, a co zawsze pozostaje niewidzialne i czego adekwatnej idei człowiek nie jest w stanie pomyśleć. Bóg w filozofii Lévinasa jest tym, co absolutnie Inne, co w żaden sposób nie daje się pojąć i sprowadzić do znanych już pojęć. 
Pragnienie jako figura metapoetycka organizuje poetycki światopogląd Leśmiana. Wpływa na kształt jego utworów oraz na ich estetykę, wykazującą pokrewieństwa z estetyką symbolistyczną, która traktowała poezję jako objawienie sensu. Ten metapoetycki wymiar pragnienia ujawnia się $\mathrm{w}$ warstwie brzmieniowej utworów. Elementy muzyczne odgrywają tu ogromną rolę. Ich najwyrazistszym przejawem jest rytmizacja. Także motyw pieśni, wielokrotnie przewijający się przez wiersze autora Łąki, jest wyrazem dążeń do ideału poezji harmonijnie łączącej człowieka z Tajemnicą, wyrażającej to, co nieuchwytne w słowach. W wierszu Romans (Napój cienisty) opowieść o dwojgu kochających się żebrakach, karmiących się nawzajem pieszczotą i chlebem, kończy się dwuwersem:

poeta, co ich widział, zgadł, jak żyć potrzeba?

Ma dwa głody, lecz brak mu - dziewczyny i chleba5 5

Można zatem rzec, że poeta to ten, kto nie żyje prawdziwe, kto z doświadczenia braku wysnuwa swoją pieśń („,śpiewam, bo śpiewam" - mówi o sobie wcześniej). W innym znanym i wielokrotnie cytowanym wierszu Poeta, pomieszczonym w tym samym tomie, czytamy autocharakterystykę poety - „niebieskiego wycierucha", który zaczarowuje za pomocą słów rzeczywistość: „słowa nawleka/ na sznur rytmu”, za nic mając prawdziwe życie, gdy „w szale występnym wiersz śpiewny układa”:

[...] Treść, gdy w rytm się stacza,

Póty w nim się kołysze, aż się przeinacza.

Chętnie łowi treść, w której łzy prawdziwe płoną -

Ale kocha naprawdę tę - przeinaczoną...

I z zachłanną radością mąci mu się głowa,

Gdy ujmie niepochwytność w dwa przyległe słowa!

A słowa się po niebie włóczą i łajdaczą -

I udają, że znaczą coś więcej, niż znaczą!...

I po tym samym niebie $-\mathrm{z}$ tamtej ułud strony -

Znawca słowa - Bóg płynie - w poetę wpatrzony. (s. 200-201)

5 B. Leśmian, Poezje, wybór, wstęp B. Zadura, Lublin 1989, s. 200. Wszystkie fragmenty wierszy Leśmiana cytuję za tym wydaniem, opatrując je numerem strony. 
Poezja jest zatem rzeczywistością „przeinaczoną”, lepszą, prawdziwszą od tej, którą znamy, za sprawą rytmu zdolną pochwycić to, co niepochwytne. W ten sposób wkraczamy w krąg estetyki symbolistycznej. Warto zwrócić uwagę na zestawienie poety $\mathrm{z}$ Bogiem wpatrzonym $\mathrm{w}$ poetę. Ten obraz swoistej konfrontacji poety $\mathrm{z}$ bóstwem pojawia się $\mathrm{w}$ twórczości Leśmiana wielokrotnie. Poeta jest bowiem tym, kto potęgą stwórczą dorównuje Bogu, kto pragnie Boga w tej kreatorskiej rywalizacji pokonać.

W artykule Rytm jako światopoglad z roku 1910 Leśmian, wskazując jako przykład potęgi działania rytmu wiersze Marii Konopnickiej, objaśnia ich wielkość następująco:

Jakaś, że się tak wyrazimy, asocjacja wszechświatowa pozwala słowom śpiewaniem przywołanym stanąć obok siebie, zestawić się, zespolić w zdanie, które jeszcze przed chwilą było obce i niedostępne dla tych zbyt ściśle określonych i odgraniczonych od siebie pojęć.

Teraz, gdy im przywróciła dusza poetki ich pierwotną treść dźwiękową, zrozumiały, iż są jeno oddzielnymi akordami jednej wielkiej symfonii. $[\ldots]$

Odzyskują harmonię naruszoną, raj utracony, w którym każde porównanie, każda przenośnia przypomina im o tajemnej łącznicy, o odwiecznym pokrewieństwie, o dziwnej - pomimo różnic tożsamości. $\mathrm{W}$ poczuciu tego pokrewieństwa i tożsamości łączą się skwapliwie - barwa z kształtem, kształt z wonią, woń z dźwiękiem, przywracając całemu światu jego jednotliwość 6 .

Warto zauważyć, że w wierszach autora Sadu rozstajnego również łatwo odnajdziemy podobne zabiegi służące odzyskaniu harmonii między słowem i światem, choć zarazem - tam, gdzie w grę wchodzi pośrednictwo słów - bezpośredniość pozostaje wyłącznie postulatem, tak jak miało to miejsce w przypadku dążeń symbolistów. Spotkamy się też z „boską swawolą” transakcentacji, którą poeta zachwala jako wyraz i świadectwo wyzwolenia słowa z wszystkich więzów i odzyskania przez nie pierwotnej swobody „nieustannych przemian twórczych oraz pierwotnej zdolności ciągłego dostosowywania się do nieokreślonej i niepochwytnej treści wabiącego je ku sobie istnienia" 7 .

${ }^{6}$ B. Leśmian, Rytm jako światopoglad, w: Pisarze awangardy dwudziestolecia międzywojennego. Autokomentarze (Leśmian - Witkacy - Schulz - Gombrowicz), wybór, oprac. T. Wójcik, Warszawa 1995, s. 42.

7 Ibidem, s. 41. Tu warto dodać, że Leśmian zdecydowanie różnił się w swych poglądach na funkcję rytmu od przedstawicieli awangardy. T. Peiper poeta również bardzo wyczulony na brzmieniową stronę poezji - podkreślał konieczność „wysubtelniania” współbrzmień, oddalania ich od siebie i cienio- 
Objaśniając niezwykłą moc rytmicznej odmiany akcentów, odnotowuje:

Dziewczýna jest rzeczownikiem, który rodzaj określa. Dziewczyná jest imieniem własnym, które osobę wyróżnia. Tamta pierwsza idzie już to w pole, już to do lasu. Ta druga idzie - w śpiew. [...] Tamta pierwsza omija ponad snem i jawą przerzucone mosty, bo ślepa a ta druga nigdy ich nie omija. Rytm je dla niej ponad otchłaniami przerzucił i drogę wskazał ${ }^{8}$.

Dziewczyna jest ulubioną bohaterką wierszy Leśmiana. Kobiety $\mathrm{z}$ jego wierszy nigdy nie mają imion, a raczej - ich imieniem jest właśnie słowo dziewczyna (zawsze, z wyjątkiem bohaterki wiersza Dziewczyna, o którym jeszcze powiemy), pisane małą literą. Co ciekawe jednak, poeta nigdy nie dokonuje zmiany akcentu akurat w tym słowie. Rzec można - posługując się ukutymi przez niego pojęciami - że jego bohaterki pozostają na granicy między realnością a poezją, między faktem życiowym a krainą Sztuki. Nie przynależąc w pełni do żadnego z tych światów, pamiętają o swoim zapośredniczonym przez słowo statusie.

Tym samym dokonania Leśmiana raz jeszcze wpisują się w ten nurt myślenia, który prowadzi symbolizm do samozaprzeczenia ${ }^{9}$. Interesującą charakterystykę tego doświadczenia

wania tak, by nie raziły łatwo wpadającymi w ucho, katarynkowymi powtórzeniami. Co ciekawe, obaj poeci wychodzą z tego samego punktu, dostrzegają bowiem związek rytmu w poezji z przemianami cywilizacyjnymi nowoczesnego społeczeństwa. O ile jednak Peiper twierdził, że współczesny człowiek znajduje się na wyższym stopniu rozwoju estetycznego i poezja powinna, nadążając za tym rozwojem, a także go stymulując, złagodzić ostrość współbrzmień, o tyle dla Leśmiana wyraźny rytm jest warunkiem istnienia poezji. Współczesny świat jest z gruntu nieprzyjazny człowiekowi twórczemu. Poeta traktuje zatem poezję jako przestrzeń ocalającą, miejsce, w którym, między innymi za sprawą rytmu, dokona się powrót do pierwotnego współodczuwania człowieka i świata. Podsumowując: dla twórcy Awangardy Krakowskiej wiersz jest narzędziem podboju rzeczywistości czekającej na zdobycie, dla autora Sadu rozstajnego - narzędziem odzyskiwania rzeczywistości utraconej.

${ }^{8}$ B. Leśmian, U źródet rytmu (Studium poetyckie), w: Pisarze awangardy dwudziestolecia międzywojennego. Autokomentarze (Leśmian - Witkacy Schulz-Gombrowicz), wybór, oprac. T. Wójcik, Warszawa 1995, s. 45.

9 Próby pokazania tej ewolucji podjął się w latach sześćdziesiątych A. Sandauer (Pośmiertny triumf Młodej Polski, w: Z problemów literatury polskiej $X X$ wieku, t. 1, red. J. Kwiatkowski, Z. Żabicki, Warszawa 1965, s. 477-498), wskazując $\mathrm{w}$ twórczości Leśmiana dwa etapy: symbolistyczny (młodopolski, tutaj zaliczył Sad rozstajny) oraz antysymbolistyczny (Łąa, Napój cienisty). Jeszcze dobitniej przekonanie o ewolucyjności tej poezji sformułował kilka lat temu P. Łopuszański (op.cit.), który wydzielił w twórczości Leśmiana cztery etapy: symbolistyczno-impresjonistyczny, parnasistowski, witalistyczny i egzystencjalistyczny. 
znajdujemy w komentarzach Paula Valéry'ego, w roku 1920 podsumowującego dokonania francuskich symbolistów: „Ale pragnienie nie może być złudne. Nie ma nic bardziej specyficznie realnego niż pragnienie jako pragnienie: podobne jest do Boga w ujęciu świętego Anzelma: jego idea i jego rzeczywistość są nierozdzielne" ${ }^{\text {Iо }}$. W ten sposób Valéry formułuje myśl o religii Sztuki, opierając ją na rzeczywistości pragnienia. Wyjaśnijmy: święty Anzelm z Canterbury wywodził ontologiczny dowód na istnienie Boga $\mathrm{z}$ faktu, że posiadamy jego ideę jako istoty najdoskonalszej. Ponieważ istnienie rzeczywiste ma dodatkowy wobec czystej idei przymiot w postaci realnego istnienia, Bóg musi jako najdoskonalszy - także ów przymiot posiadać, a więc musi istnieć. $\mathrm{W}$ ten sposób pragnienie Boga zrównane zostało $\mathrm{z}$ jego istnieniem. Valéry, odwołując się do teologicznego wywodu św. Anzelma, tę samą zasadę stosuje w odniesieniu do poezji. Stwierdzenie, że „pragnienie nie może być złudne”, świadczy o zrównaniu subiektywnego doświadczenia z tym, co rzeczywiste. To dlatego symboliści tak poważnie traktowali wizyjność, przeczucia i intuicje: wszystkie te doznania uważali za świadectwa istnienia celu, do którego dążyli. Można zatem powiedzieć, że opierali swój projekt na pewnym realnym dla nich doświadczeniu metafizycznym. Valéry wielokrotnie pisał na temat pragnienia Absolutu jako doświadczenia kluczowego dla poezji. Szukając definicji piękna jako celu, do którego zmierza poezja, zauważał: „ «Piękno» oznacza «niewyrażalność» - (i pragnienie, aby doświadczyć tego wrażenia na nowo)" ${ }^{\text {II }}$.

Każde spotkanie z pięknem budzi w nas poczucie niemożności jego wyrażenia w każdym systemie środków wyrazów. Piękno jest niewysłowione, to znaczy: brakuje słów, by je wyrazić. Ale to właśnie literatura (Valéry ma na myśli przede wszystkim poezję) „poprzez «słowa» próbuje stworzyć «stan braku słów»" ${ }^{2}$. Podkreślić warto czasownik „próbuje”, wskazujący jasno na projektujący, życzeniowy charakter tej wizji. Jego nieosiągalność stanowi impuls i motywację do ciągłych poszukiwań: „Piękno to zatem negacja, plus pragnienie, jakie budzi w nas to, co wyraża się tą niemożnością, pl u s «nieskończoność» tego

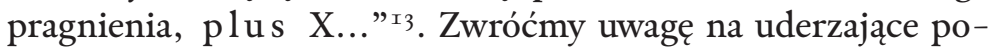
dobieństwo Leśmianowej koncepcji poezji jako słów do „pieśni

ro P. Valéry, Pierwszy krok do poznania bogini, w: idem, Estetyka stowa. Szkice, wybór A. Frybesowa, wstęp M. Żurowski, przeł. D. Eska, A. Frybesowa, Warszawa 1971, s. 139.

II P. Valéry, Cbwile, w: Estetyka stowa. Szkice, wybór A. Frybesowa, wstęp M. Żurowski, przeł. D. Eska, A. Frybesowa, Warszawa 1971, s. 240.

I2 Ibidem, s. 241.

I3 Ibidem. 
bez słów" i Valéry'ego definicji poematu jako szukania słowa dla tego, co niewyrażalne. Jeśli jednak symboliści ponieśli klęskę co Valéry sam przyznaje - to dlatego, że osiągnięcie celu byłoby sprzeczne z samą jego naturą. Czyste, absolutne piękno, podobnie jak Bóg, jest doskonałe, stanowi granicę świata, na której nie sposób przebywać:

Nic tak czystego nie może istnieć w warunkach życia. Przechodzimy tylko przez ideę doskonałości, tak jak dłoń bezkarnie rozcina płomień; ale mieszkać w płomieniu nie można, a najwyższe przybytki czystego pokoju muszą być puste ${ }^{\mathrm{I}}$.

Podsumowanie dokonań symbolistów w dążeniu do czystego piękna Valéry zamyka w wyznaniu: „Ale myśmy byli wykarmieni muzyką i nasze literackie mózgi marzyły tylko o jednym: wydobyć z języka te same niemal efekty, jakie w naszych wyczulonych duszach budziły bodźce czysto dźwiękowe" ${ }^{5}$.

We wspomnieniu poświęconym pamięci Stéphane'a Mallarmégo Valéry mówi wprost o magicznej, pierwotnej sile słów, których skuteczność zasadzała się nie na znaczeniu, ale na niezwykłym brzmieniu i formie:

Otóż poezja związana jest bez wątpienia z pewnym okresem rozwoju człowieka, wcześniejszym niż pismo i zdolność krytycznego myślenia. Toteż każdy prawdziwy poeta jest w moich oczach takim człowiekiem minionych epok: czerpie nadal ze źródeł języka $^{\text {I6 }}$.

Valéry sformułował przywołane tu uwagi na przestrzeni lat dwudziestych XX wieku. Leśmian nie mógł ich znać, kształtując własny sposób myślenia o poezji, jednakże poglądy Valéry’ego jako reprezentatywne dla symbolistycznej estetyki i wrażliwości w oczywisty sposób obecne były w świadomości twórców i odbiorców poezji tego okresu. Leśmian w dążeniu do umuzykalnienia poezji, w swej oryginalnej koncepcji pieśni bez słów, w niezwykłej korespondencji między istnieniami osiąganej za sprawą rytmu, w wyobrażeniu poety jako istoty nad-ludzkiej, pamiętającej o swym obcowaniu z bóstwem (wiersz Akteon z tomu Napój cienisty), w konsekwentnym przekraczaniu granic ontologicz-

${ }_{4} 4$ P. Valéry, Pierweszy krok..., s. 139.

I5 Ibidem, s. 135.

I6 P. Valéry, Mawiatem czasem do Stefana Mallarmé..., w: Estetyka stowa. Szkice, wybór A. Frybesowa, wstęp M. Żurowski, przeł. D. Eska, A. Frybesowa, Warszawa 1971, s. 193. 
nych, a wreszcie w traktowaniu pragnienia jako łącznika między tym, co nieosiągalne, a dążeniem, prezentuje się jako poeta wywodzący się z doświadczenia symbolizmu. Jest to jednak symbolista zdystansowany, świadom nierealności tego projektu; symbolista doprowadzający projekt zniesienia granic między tym, co rzeczywiste, i tym, co poetyckie do kresu, lecz zarazem obarczony świadomością teatralności gestów, jakie wykonuje.

3.

W świecie przedstawionym utworów Leśmiana pragnienie jest też figurą antropologiczno-egzystencjalną. Odnosi się do stanu lirycznego „ja”, a także bohaterów, spragnionych bliskości, miłości i wzajemności uczuć, jednocześnie niespełnionych w swych tęsknotach. Leśmianowskie postaci pragnące zawsze obarczone są jakimś widocznym brakiem, dysfunkcją fizyczną: poruszają się na wózku inwalidzkim, mają garb, drewniane nogi, są brzydkie i kalekie. Ta widoczna ułomność staje się zewnętrznym wyrazem braku duchowego - bo przecież bohaterowie nie marzą o tym, aby wyzdrowieć, zdobyć bogactwo i urodę, lecz by znalazł się ktoś, kto wypełni ich pustkę wewnętrzną, kto zaspokoi żądze, a także ujrzy w nich pełnoprawną istotę, zasługującą na miłość. To jednak nie spełnienie, lecz pożądanie stanowi warunek ich istnienia. Wszyscy bohaterowie podsycają swoje pragnienie pragnieniem, kochankowie spieszą się „spragnieni tęsknoty bezkreśnej' (Schadzka w tomie Sad rozstajny), potęgują je tak, jak dwunastu młodzieńców chcących dotrzeć do dziewczyny, której głos słyszą zza muru (Dziewczyna). Pragnienie definiuje los człowieka dążącego do celu. Przy czym większość z nich nigdy nie osiąga stanu, za którym tęskni, zaś ci, którym się to udaje, przeżywają rozczarowanie i... dalej pragną. Życie jest bowiem ruchem, a każde zaspokojenie unieruchamia, pozbawia woli dążenia, a zatem jest sprzeczne z zasadą życia, zwiastuje śmierć.

Pragnienie łączy się więc $\mathrm{z}$ antropologiczną kategorią doświadczenia, należy bowiem do fenomenów, bez których subiektywność jest nie do pomyślenia. W pragnieniu wielką rolę odgrywają zmysły, cielesność, to, że człowiek pragnie doznawać. Nie jest to bowiem ani akt intelektualny, ani mentalny, tylko organiczny. Tak definiuje się pragnienie zarówno w filozofii indyjskiej, jak i w tradycji hebrajskiej. Podział na sferę duchową i cielesną jest sztuczny i stosunkowo późny, bo wprowadzony przez chrześcijaństwo. Leśmian także pojmuje pragnienie holi- 
stycznie, nie oddzielając doświadczeń właściwych duszy od tych danych ciału. Tak jest na przykład w wypadku bohatera Nieznanej podróży Sindbada Żeglarza (Sad rozstajny), który doświadcza duchowej pustki z powodu miłosnego zawodu. To dziewczyna „Nieobecnością ciała w [jego - E.W.] objęciu/ Pustosząc ducha, co w nic się rozdzwania" (s. 51), sprowokowała podróż po morzach, będącą ucieczką od celu pragnień i poszukiwaniem „obiektu zastępczego”. Podobnie dzieje się z tytułowym Topielcem (Łąka), który zapragnął „Zwiedzić duchem na przełaj zieleń samą w sobie" (s. 83) i zatonął już na zawsze w zieleni. Analogiczny los spotyka także innych bohaterów Leśmiana. Kwintesencją tego doświadczenia, zbierającego w nierozłączną całość zarówno impulsy erotyczne, jak i metafizyczną potrzebę uciszenia tęsknot duszy, jest wiersz Pragnieniez tomu Łąka:

Chciałbym w lesie, w ostępach dzikiego błędowia,

Mieć chałupę - plecionkę z chrustu i sitowia,

Zawieszoną wysoko w zagłębiach konarów

Nad otchłanią jam rysich i wężowych jarów.

Tam na mchu, kołysany obłędną wichurą,

Chciałbym pieścić dziewczynę obcą i ponurą,

Głaskać piersi ze świeżą od mych zębów raną

I całować twarz, ustom jako łup podaną -

I słyszeć, jak dokoła grzechu mej pieszczoty

Pląsa burza skuszona i mdleje grom złoty,

I zwierz ryczy, ciał naszych przywabiony wonią,

Ciał górnych, wniebowziętych, co od ziemi stronią -

I chciałbym przez przygodny wśród gałęzi przezior

Patrzeć, piszcząc, w noc - w gwiazdy i w błyskania jezior

I za boga brać wszelkie lśniwo u błękitu,

I na piersi dziewczęcej doczekać do świtu,

A słońce witać krzykiem i wrzaskiem i wyciem,

Żyć na oślep, nie wiedząc, że to zwie się życiem -

I pewnej nocy przez sen zaśmiać się w twarz niebu

I nie znając pokuty, modlitw ni pogrzebu,

Jak owoc, co się paszczy żarłocznej spodziewa,

Z łoskotem i łomotem w mrok śmierci spaść z drzewa! (s. 147)

Utwór ten doskonale odzwierciedla ideę pierwotności jako utraconego bezpowrotnie stanu. W artykule Znaczenie pośrednictwa w metafizyce życia zbiorowego z roku 1910 znajdujemy podstawowe rozróżnienia, na których Leśmian buduje swój światopogląd. Pierwotność oznacza metafizyczność więzi duszy ze światem; język człowieka pierwotnego jest odbiciem rytmu 
jako tego, co wcześniejsze od znaczenia, co zbliża do niematerialnej, „bezcielesnej kanwy dla swego czystego myślenia” ${ }^{17}$. Czym jest owo „czyste myślenie"? Otóż człowiek pierwotny nie rozdzielał życia od myślenia. Praktyki od teorii - powiedzielibyśmy dzisiaj. Człowiek pierwotny, twórczy „posiadał więc życie metafizyczne, bezpośredniej związane, pokrewniejsze żywiołom" i percypował świat intuicyjnie, kierując się pierwotnym instynktem: „przemyśliwał obrazy”; nie snuł autorefleksji, by „s z u kać s i e bi e”, bo „był sobą od razu”. Świat, w którym człowiek nadawał kształt rzeczywistości, w którym panowała pełna harmonia między formą i treścią, to świat, w którym człowiek był zadomowiony. Nawet Bóg był „przedłużeniem w nieskończoność, rozrostem w błękit istoty ludzkiej, która wszechświat poznaje zaborczo, nadając mu swoje własne prawa i odnajdując w nim obraz i podobieństwo swoje". Tak pojmowany człowiek obdarzony jest boską, stwórczą mocą, łączy dwa, potem już na zawsze rozdzielone, światy: ziemię i niebo, siebie i bogów, ciało i duszę. Ten pierwotny człowiek nie ma zatem nic wspólnego ze zdziczeniem, przeciwnie: „odznacza się właśnie większym stopniem uduchowienia i uzdolnień metafizycznych”. Sytuację człowieka metafizycznego w opozycji do współczesnego stanu Leśmian charakteryzował następująco:

O ile my, dzięki metodom naukowym, sami dla siebie staliśmy się eksperymentem, zadaniem do rozwiązania, i rozchwiani na tysiące przypuszczeń i domysłów, dążymy do tego, aby na nowo stać się sobą, o tyle on - nie rozchwiany, nie przeobrażony w zagadnienie, pragnął właśnie przestać być sobą, powrócić do wszechświata, który go wyłonił, pogrą̇żć się w nirwanie. To pragnienie było - pragnieniem szczęścia, było jego o p t y $\mathrm{m}$ i z $\mathrm{m}$ e $\mathrm{m}$. Dla nas jest to pesymizm $^{\mathrm{I} 8}$.

Nowoczesny światopogląd Leśmiana manifestuje się w przekonaniu o tym, że współczesny człowiek został wydziedziczony z własnej tożsamości. Dziś brakuje mu całokształtności i żywiołowości: poznaje świat intelektem, żyje w przestrzeni myślowej abstrakcji, dorabia do niej obrazy: pojęcia, nazwy, klasyfikacje. Wiersz Pragnienie wyraża tęsknotę za stanem, w którym nie ma rozdźwięku między istnieniem i świadomością istnienia, w któ-

${ }_{7}$ B. Leśmian, Znaczenie pośrednictwa..., w: Pisarze awangardy dwudziestolecia międzywojennego. Autokomentarze (Leśmian - Witkacy - Schulz-Gombrowicz), wybór, oprac. T. Wójcik, Warszawa 1995, s. 22. Kolejne cytaty z tej i następnej strony.

I8 Ibidem, s. 24. 
rym podmiot roztapiał się w żywiole życia. Powrót do tak rozumianej pierwotności jest oczywiście mitem. Poeta może jedynie inscenizować taki stan, nie da się bowiem utracić raz uzyskanej świadomości.

4.

Równie ważny, jeśli nie ważniejszy, jest wymiar epistemologiczny pragnienia: jest ono siłą napędową poczynań bohaterów, dążących do zgłębienia tajemnicy bytu. Tu trzeba odwołać się do filozofii życia, przede wszystkim Bergsona i Nietzschego, których antysubstancjalne ujęcie aktywizmu i nieokiełznanego żywiołu znajduje w poezji Leśmiana świetną realizację. Wszystkie pragnienia są bowiem energiami, mają charakter „popędowo-

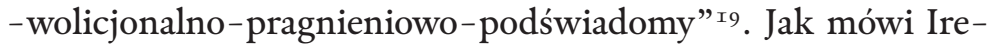
neusz Kania, „pragnienie to jest pierwszy impuls podmiotu, który odczuwa jakiś brak [...] i usiłuje ten brak jakoś przezwyciężyć. A w tym celu musi wyjść poza siebie, musi transcendować samego siebie" ${ }^{20}$.

Aby pokazać ten energetyczny wymiar pragnień, zatrzymajmy się przy cyklu Zielona godzina (Sad rozstajny). Możemy go interpretować jako rodzaj niezwykłego widowiska ujętego w ramy snu. Już tytuł wskazuje na szczególność czasu, w którym rozgrywać się będą zdarzenia poprzedzone przez ruch "gałęzi wahadła”, gdy te, „Snem trącone”, zaczęły wybijać Zieloną Godzinę. To sygnał do rozpoczęcia spektaklu. Przed nami odbywa się „intermedium istnienia” ${ }^{21}$, w którym magiczne porozumienie między bohaterem - poetą a lasem, będącym tu metonimią świata natury, dokonuje się bez słów. By człowiek mógł zrozumieć „gęstwy zieleni", niepotrzebne jest pośrednictwo nazw. Ten, który znalazł się w zielonej otchłani, sam jest snem lasu, w którym idzie „Ku bezcelom, zapadłym w nieprzebytą ciszę,/ Gdzie wszystko jest - bez nazwy, bez granic, bez tchu" (s. 27). Poeta mówi: „Śmiech mój i me nadzieje patrzą w wonny świat!” (s. 28). Bohater traci swoją odrębność: jest tym, co sam czuje - śmiechem i nadzieją, zaczyna doświadczać świata takiego, jakim jest jeszcze nienazwany, a zatem istniejący poza porządkiem trady-

I9 Pragnienie wzbronione? Z Marta Kudelska i Ireneuszem Kania rozmawia Krzyysztof Bielawski, „Mêlée” 2008, nr 2/3, s. 182.

${ }_{20}$ Ibidem, s. 174.

2I Określenie to pochodzi z dramy mimicznej B. Leśmiana Skrzypek Opętany (oprac., wstęp R.H. Stone, Warszawa 1985) i odnosi się do stanów (sen, marzenie, sztuka), w których możliwa jest niezapośredniczona, pozasłowna komunikacja. 
cyjnej kosmogonii wiążącej istnienie bytów $\mathrm{z}$ ich nazywaniem i poza porządkiem epistemologii europejskiej kultury opartej na podmiotowo-przedmiotowym dualizmie poznawczym:

Skwar widmem złotych siekier uderzył w drzew thumy!

Trzebaż im ponadawać raz jeszcze imiona,

By je poznać w zamęcie upalnego snu? (s. 29)

W tym „niestworzonym”, będącym sennym widziadłem, lesie dziać się zaczynają rzeczy niezwykłe. Przyroda ożywa, a człowiek traci swą ludzką tożsamość, czego wyrazem jest utrata twarzy:

Czyjaż dusza w twe gąszcze znowu się zapadła?

Czyjaż twarz się strumieniom twoim przypomina?

Jeszcze moja przed chwilą - już niczyja twarz... (s. 24)

Co ciekawe - leśne gęstwiny, widzące twarz gościa, rozpoznają w niej to, co należy do nich: „To - ona!/ Zbłąkaną poza nami - Bóg przywrócił nam!...”. W ten sposób rozpoczyna się żywiołowa dyfuzja tego, co ludzkie i leśne. Rzeczy stają się, jak u Bergsona, działaniem. Filozof twierdził, że tak naprawdę świat jest ruchem, natomiast rzeczy są konstrukcjami podmiotu:

Jak kłęby kurzu podnoszone przez wiatr, tak żywe istoty kręcą się $\mathrm{w}$ wirze wznoszonym przez wielkie tchnienie życia. Są więc one względnie stałe, a nawet tak dobrze naśladują nieruchomość, że traktujemy je raczej jako rzeczy niż jako rozwój, zapominając, że sama stałość ich formy jest tylko konturem pewnego ruchu. Niekiedy jednak niewidzialny podmuch, który je unosi, materializuje się w przelotnym zjawisku na naszych oczach ${ }^{22}$.

Przyroda, człowiek, świat cały są ciągłym wirowaniem, w którym trudno oddzielić byt od bytu, w którym wszystko przenika się i kipi wolą życia. Dzieje się tak, jakby zapachy, dźwięki, doznania dotykowe i wizualne docierały do podmiotu, przenikając go „na wskroś” ${ }^{23}$, po to, by natychmiast zniknąć, wyparte przez kolejne doznania. Powrót do stanu świadomości intuicyjnej łączy się z doświadczeniem absolutnej wolności: wyzwolenia z więzów społecznych, poznawczych, ale i moralnych:

${ }^{22}$ H. Bergson, Ewolucja twórcza, w: idem, Pamięć $i$ życie, przeł. A. Szczepańska, wybór G. Deleuze, Warszawa 2001, s. 99.

23 M.P. Markowski, op.cit., s. 134. 
Nie znam granic ni kresów! Pożądam i płonę!

Płonący wołam światu: Razem ze mną płoń! (s. 26)

To, co dzieje się w przestrzeni przedstawionej Leśmianowych wierszy, jest natłokiem istnień działających na oślep, prących ku życiu. To świat oczyszczony z intelektualnych konstrukcji, trzeźwych kalkulacji, świat będący czystą biologią, élan vital. Biologizm życia jest płaszczyzną, na której człowiek traktuje siebie jako część przyrody. Bohater też staje się jej częścią. Ale częścią, zachowującą swą odrębność, wynikającą z pamięci o innym świecie, przeciwko któremu się buntuje. Doświadcza on świata w nieustannie zmieniającym się tu i teraz, choć sam tylko połowicznie rozprasza się w swych doznaniach, towarzyszy mu bowiem niby cień drugie „ja” - to, które wspomina całą historię i opowiada ją, już przy użyciu słów. Nie jest on zatem zwykłym człowiekiem, żyje bowiem w dwóch światach, ma też coś, czego nie ma las: ducha, pierwiastek łączący go z nieskończonością, i świadomość, która oddala go od spontaniczności i bezpośredniości przeżywania:

Jam czekał, aż się moje sny ku niemu zziemszczą,

Aby w cieniu paproci zrosić swe otchłanie,

A on czekał, aż w nim się rozlegnie mój duch. (s. 31)

Liryczne „ja” jest zbudowane na antytezach. Definiuje siebie jako: „miejsce spotkania łez ze złotym kurzem/ Słońca” (s. 27); jako skrzyżowanie cierpienia i witalizmu natury. Tym też różni się od przyrody, która jest czystą energią, żywiołem, nieustannie tryskającą fontanną fajerwerków tworzących nowe byty. On zaś jest „inny, niepodobny - odmieniec i dziw!”. Jest odmieńcem zarówno w świecie natury, która nie wie, czym są łzy, cierpienie i ból, jak i w świecie ludzi, do których ten, kto mówi o sobie, że jest „światów tajemnych zjawionym przedmurzem” i „marzeń dźwigaczem", zupełnie nie pasuje.

Poetycka epistemologia Leśmiana oparta jest na doświadczeniu zmysłowym. Jego bohater poznaje świat duchem, który jest metonimią pierwotnej intuicji i prawie zwierzęcego instynktu:

Duchu mój, wrażę ciebie, niby dziób bociani,

W mokradła, żab oddechem nabrzmiałe i wzdęte,

Byś poznał woń pod ziemią zaczajonych wód! (s. 24-25)

Jednocześnie jest to rodzaj doświadczenia, którego specyfikę celnie zdefiniował Ryszard Nycz, podkreślając, że Leśmian 
utrwala epifanijność zdarzeń: to, że coś się wydarza, choć zarazem trudno określić, czym było to, co się zjawiło. Znika bowiem, pozostawiając po sobie zaledwie „auratyczny ślad swej obecności” ${ }^{24}$. Ta ulotność autentycznego doświadczenia obecności sprawia, że

zdarzenia ujęte zostają $\mathrm{z}$ perspektywy nieredukowalnego, wewnętrznego dystansu, który tyleż umożliwia wydobycie i doświadczenie autentyzmu oraz wyjątkowości jego zaistnienia, co, z drugiej strony, uprzytamnia niemożliwość jego przedstawienia; tzn. przedstawienia momentu jego nastawania w unikalności bycia 'teraz', uchwycenia obecności ${ }^{25}$.

Nawet kiedy konkretne osoby i zdarzenia dotykają bohatera, to pomiędzy nim a światem pozostaje minimalne oddalenie. Nie jest to skutek zobiektywizowanego usytuowania podmiotu kontemplacyjnego ${ }^{26}$, lecz rodzaj doświadczenia znikliwości i nieuchwytności tego, co się wydarza. To doświadczenie wewnętrznego dystansu jest czymś, co stanowi paradoks tej poezji: cała historia zostaje przecież przedstawiona w słowach. Więcej nawet: okazuje się, że jako sen wyśniony przez las nie istnieje ona poza wysłowieniem poetyckim. To poezja przywraca ten niezwykły stan pierwotnej harmonii, lecz doznaniom bohatera towarzyszy nieustannie liryczne „ja”, które komentuje z perspektywy, należącej już do innego niż czas magicznej Zielonej Godziny wymiaru, „czym byłem dla ciebie w twym śnie?” (s. 30) - zadaje pytanie lasowi, a w kolejnym wierszu informuje: „Cofnęliśmy się [las i ja - E.W.] - każde w swą ciemność, w swój świat” (s. 31).

5.

Okazuje się jednak, że świat jest niepoznawalny, w duchu bergsonowskiego élan vital jest jak jeden $\mathrm{z}$ wielu wytryskujących nieustannie rac-światów ${ }^{27}$. I oto pragnienie epistemologiczne

${ }_{24}$ R. Nycz, op.cit., s. 134.

25 Ibidem, s. 133-134.

${ }_{26}$ M.P. Markowski (op.cit., s. 134) słusznie zauważa, że „świat jest zbyt blisko podmiotu, by można było od niego się zdystansować”.

27 Por. wypowiedź Bergsona (op.cit., s. 136) o Bogu jako o „ośrodku, z którego wytryskiwałyby światy jak race z ogromnego fajerwerku - byleby nie traktować tego ośrodka jako rzeczy, lecz jako ciągłość wytryskiwania. Bóg tak określony nie ma w sobie nic gotowego; jest on nieprzerwanym życiem, działaniem, wolnością. Stworzenie tak pojęte jest tajemnicą, doświadczamy go w sobie, gdy tylko swobodnie działamy". 
generuje z samego siebie nowe byty, wyrywa się ku nieskończoności, ku zaświatowi, ku niebytowi (wszystkie byty zaprzeczone traktujemy tu w aspekcie pozytywnym - jako odmienne formy istnienia), stając się fundamentem istnienia. Pragnienie jest więc także figurą ontologiczną: to z niego wypływają nieustanne metamorfozy natury; jest także źródłem nie-tożsamości podmiotu tych wierszy, noszącego cechy Narcyza i dziecka z Lacanowskiej opowieści o lustrze, który lekcję poznawania „ja” zrozumiał po swojemu.

Figura pragnienia, odzwierciedlająca stan dynamicznego nienasycenia, wiecznego dążenia, bez możliwości i nadziei na osiągnięcie celu, sugestywnie oddaje specyfikę tej poezji. W praktyce lekturowej przeważnie nie da się rozdzielić doświadczenia estetycznego, egzystencjalnego, epistemologicznego i ontologicznego - są one stopniami tej samej wszechobecnej w świecie Leśmiana figury, przenikają się bowiem i płynnie przechodzą $\mathrm{w}$ siebie. We wszystkich wskazanych przeze mnie odmianach pragnienia wyjściowym stanem jest nieprzekraczalny dystans między pragnącym i tym, co stanowi przedmiot pragnienia, które za Lévinasem, choć wbrew znaczeniu przypisywanemu przezeń temu pojęciu, moglibyśmy nazwać upragnionym ${ }^{28}$.

Czym będzie to upragnione w poezji Leśmiana? W doświadczeniu estetycznym - ideałem poezji, realizacją idei słów do „pieśni bez słów”. W doświadczeniu antropologiczno-egzystencjalnym - poczuciem bezpośredniości i harmonii z sobą samym i każdym istnieniem, doświadczeniem pełni istnienia, której najczęściej przywoływaną figurą jest spełnienie erotyczne. W perspektywie poznawczej - zgłębieniem tajemnicy bytu.

We wszystkich przypadkach chodzi o stan doświadczenia pełni, obecności. Doskonałość jest jednak stabilnym stanem, zaś w świecie Leśmiana nie ma miejsca na trwałość. Wszechświat Leśmiana rozszerza się $\mathrm{w}$ nieskończoność, pozbawiony jest teleologii. Nawet śmierć obecna w tej poezji jako druga strona życia nie jest przecież ostatecznym końcem. Wielu bohaterów Leśmianowskich przekracza granicę śmierci, która jest tylko przejściem w inny stan istnienia. Tak jakby wola życia była energią przechodzącą ze stanu w stan przy swej niezmiennej sumie.

A zatem upragnione Leśmiana po prostu nie istnieje. Czy raczej jest pewnym wyobrażeniem warunkującym życie, lecz nigdy nieosiągalnym. Mówiąc jeszcze inaczej: tym celem jest samo pragnienie. W ten sposób każda ze wskazanych figur odsyła, rzecz jasna, do doświadczenia metafizycznego, które jest istotą

${ }_{28}^{8}$ Por. E. Lévinas, op.cit., s. 18-21. 
nieziszczalności pragnienia; każda łączy w sobie doświadczenie estetyczne, antropologiczne i religijne. Dlatego relacja z tym, co wyobrażone-upragnione, zawsze jest zbudowana na niepokonywalnym dystansie; zakłada zależność opartą na oddaleniu i separacji, bo, jak tłumaczy filozof, „karmi się ona swoim własnym głodem" ${ }^{29}$.

6.

Rolę pragnienia $\mathrm{w}$ poezji Leśmiana świetnie ilustruje wiersz Dziewczyna z tomu Napój cienisty (1936), opublikowany po raz pierwszy w 1933 roku. Należy on do późnego okresu twórczości poety, w którym dominują wątki egzystencjalistyczne: dynamizm i pęd życia zastępuje refleksja nad przemijaniem, zamiast twórczej omnipotencji podmiotu tematem dominującym staje się nietrwała kondycja człowieka zmierzającego ku śmierci.

Dziewczyna stanowi jeden z najbardziej znanych, a zarazem niezwykłych i zagadkowych utworów poety. Interpretowany przez niemal wszystkich badaczy tej twórczości, odczytywany był najczęściej jako wiersz o dążeniu do celu, który sam jest wielkim złudzeniem. Tak uważają Kazimierz Wyka, Jacek Trznadel (ten uzupełnił swoje odczytanie wnioskiem o heroizmie ludzkich działań) i Tymoteusz Karpowicz ${ }^{3}$. Z kolei według Cezarego Rowińskiego $^{3 \mathrm{I}}$ Dziewczyna to przypowieść o nieśmiertelnej woli, która nie ginie wraz ze śmiercią jej właściciela, oraz o rozczarowaniu świadomości, gdy cel zostanie osiąnnięty. Trafne wydaje się tu wyeksponowanie Schopenhauerowskiego pojęcia woli,

29 Ibidem, s. 19. Do cech tego pragnienia należą: radykalność i absolutność. Nie może ono antycypować Upragnionego, to ostatnie jest bowiem niewyobrażalne i nieprzewidywalne, podobnie jak śmierć. Kategoria Upragnionego mieści się więc poza światłem i mrokiem poznania: pragnienie jest „pragnieniem absolutnie Innego" (idibem, s. 20), jest poza zmysłami, które można ukoić i poza głodem, który można nasycić. Stąd w pragnieniu metafizycznym kryje się pierwiastek irracjonalny - nie da się aktów dokonywanych pod jego wpływem uzasadnić logicznie, a ruch, który ono zakłada, jest transcendentny: „Transcendencja przypisywana temu ruchowi ma tę osobliwość, że dystans, jaki wyraża - w odróżnieniu od każdej zwykłej odległości - konstytuuje sposób istnienia zewnętrznego bytu. Jego charakterystyka formalna - bycie innym stanowi jego treść. Dlatego metafizyk i Inne nie tworzą razem całości. Metafizyk jest absolutnie odseparowany". Ibidem, s. 21.

$3^{\circ}$ Zob. K. Wyka, Bolestaw Leśmian: dwa utwory („Dusiołek”, „Dziewczyna"), w: Liryka polska. Interpretacje, red. J. Prokop, J. Sławiński, Kraków 1966; J. Trznadel, Twórczość Leśmiana (próba przekroju), Warszawa 1964; T. Karpowicz, Poezja niemożliwa. Modele Leśmianowskiej wyobraźni, Wrocław 1975.

${ }^{1}$ Zob. C. Rowiński, Człowiek $i$ świat w poezji Leśmiana. Studium filozoficznych koncepcji poety, Warszawa 1982. 
tożsamego dla tego filozofa z wolą życia. Do kwestii tej jeszcze powrócę. Wśród najnowszych odczytań na szczególną uwagę zasługują dwa: Pawła Dybla i Michała Pawła Markowskiego. Im też chciałabym najpierw poświęcić uwagę.

Dybel posłużył się w swojej interpretacji psychoanalizą. Odwołał się do Lacanowskiej koncepcji podmiotowości, w której niezbędnym warunkiem narodzin „ja” jest ujrzenie siebie w zwierciadlanym odbiciu. Dziecko, utożsamiające się do tej pory $\mathrm{z}$ matką-rzeczą, widzi odbity obraz siebie. Traktuje ten lustrzany wizerunek jako innego siebie - swoje „ja idealne”, które pozwala mu zapanować nad chaosem własnego zdezintegrowanego ciała. Ten moment rozpoznania $\mathrm{w}$ zwierciadlanym odbiciu staje się początkiem świadomości podmiotu. Odbity obraz pojawia się i kształtuje po stronie wyobraźni, oddzielonej od sfery realnej. Obiekt wyobrażony przez podmiot, nazywany przez Lacana objet petit a, jest obiektem zastępczym - wyobrażeniowym substytutem tego, co wcześniej zostało przezeń na zawsze utracone: pełnej identyfikacji i dostępu do matki-rzeczy, kiedy nie było podziału na to, co zewnętrzne i wewnętrzne, na „ja” i innych. Faza lustra jest zwrotnym momentem w formowaniu się podmiotowości. Jak pisze Dybel, ,utracony raz na zawsze obiekt pragnienia od tej pory trwale zakreśli horyzont ludzkiej historii, powracając w niej od tej pory pod postacią różnych wyobrażeniowych substytutów" ${ }^{2}$. Podmiot, naznaczony poczuciem braku po utracie matki-rzeczy, do końca życia będzie dążył do odzyskania utraconego obiektu, którego funkcję pełni „ja” idealne.

Badacz odtwarza tę sytuację w Dziewczynie Leśmiana. W charakterze wyobrażonego obiektu występuje tu głos dziewczyny. Zamiast lustra pojawia się mur, który nie przynosi obrazu innego siebie, lecz głos. Nie jest to jednak głos rzeczywisty, lecz zaledwie jego wyobrażenie (świadczą o tym określenia odnoszące się do tego, co za murem: „marzeń strona”, „głos zaprzepaszczony”, „chętny domysł”, „sen” [s. 176]). Pełniąc funkcję objet petit $a$, głos ów jest ze swej istoty nieosiaggalny i właśnie $\mathrm{z}$ tego powodu rodzi on pragnienie podmiotu, który odtąd przez całe życie ściga go bezskutecznie:

Objet petit a łączy zatem w sobie dwie przeciwstawne cechy: jest nieobiektywizowany, płynny, ciągle rozwiewa się w nicość (nie można o nim w ogóle powiedzieć, że istnieje) i zarazem kryje w sobie pewien nadmiar, ciągłą obietnicę "pochwycenia” siebie, pobudzając w ten

$3^{2}$ P. Dybel, Urwane ścieżki: Przybyszeweski - Freud - Lacan, Kraków 2000, s. 259. 
sposób wyobraźnię podmiotu. Sprawia zatem, że w życiu podmiotu zaczyna się coś „dziać”, zostaje ono w jakimś sensie wypełnione, zyskuje pewną konkretność, kształty, jest na coś nastawione ${ }^{33}$.

Ponieważ jednak głos-obiekt pragnienia jest tym, co warunkuje normalne funkcjonowanie podmiotu, rozbicie muru-lustra nie prowadzi do odnalezienia dziewczyny, lecz do katastrofy. Bracia znoszą bowiem „niezbędny dystans” ${ }^{34}$ między własnym pragnieniem i jego obiektem. Bez tego dystansu zaś, jak zauważa w swoim komentarzu Markowski, „człowiek nie może być człowiekiem" ${ }^{35}$. A zatem mur marzeń to iluzja warunkująca normalne życie. Rozbicie go przez braci jest zamachem na samych siebie. Pragnienie dotarcia do zaprzepaszczonego dziewczęcego głosu zostaje przeniesione na pragnienie rozbicia muru. Praca braci jest echem pierwszego pragnienia - ujrzenia właścicielki głosu. „Jest pragnieniem tamtego pragnienia...” - pisze Dybel ${ }^{36}$. Jak widać, zwraca on uwagę przede wszystkim na te fragmenty wiersza, które mieszczą się w perspektywie analizy pragnienia. Słabością tej interpretacji, przy całej wirtuozerii, z jaką badacz pokazał analogie między Lacanem i Leśmianem, jest w gruncie rzeczy instrumentalne posłużenie się interpretowanym wierszem po to, by pokazać zaskakujące, acz przypadkowe, zbieżności między intuicjami poety i teorią psychoanalityczną.

Z kolei Markowski, wychodząc z założenia, że sen jest u Leśmiana synonimem poezji, pokazuje, że w wierszu chodzi o to, „jak należy rozumieć literaturę” 37 . A należy ją rozumieć jako domenę iluzji słów, które udają, że odsyłają do czegoś, co istnieje poza nimi. Bracia są tu metonimią naiwnych czytelników, wierzących $\mathrm{w}$ to, że poza słowami kryje się jakaś rzeczywistość ${ }^{8}$. Markowski także, podobnie jak Dybel, skupia się na początko-

33 Ibidem, s. 257.

34 Ibidem, s. 247.

35 M.P. Markowski, op.cit., s. 148-149.

${ }^{6}$ P. Dybel, op.cit., s. 246.

37 M.P. Markowski, op.cit., s. 149.

$3^{8}$ „Bracia wierzą w sny, tak jak się wierzy w literaturę (przecież poezja i sen to dla Leśmiana synonimy), ale jednocześnie nie wierzą, że w literaturze nie ludzie mówią (ludzie mówią do siebie poza tekstami), lecz same słowa, odjęte jakiekolwiek postaci. Jeśli za murem (za tekstem) niczego i nikogo nie ma, to znaczy to, że literatura podszyta jest nicością i to właśnie z tym nie mogą się pogodzić bracia [...]. A co to znaczy, że literatura podszyta jest nicością? To, że poza nią nie ma nic. Założyć, że dziewczyna istnieje realnie, poza wierszem, to ją „zaprzepaścić”. Natomiast założyć, że dziewczyna to tylko słowa, które brzmią, to ocalić świat poezji od codziennej rzeczywistości. Tak więc także można interpretować Dziewczynę: jako wiersz o klęsce czytania dobrodusznego, które za tekstem musi widzieć rzeczywistość, bo inaczej nie pokocha literatury". Ibidem, s. 149. 
wej i końcowej części wiersza, pomijając fragment o pracujących po śmierci braci ich cieniach, a następnie - samych młotach.

Tymczasem utwór ten można też potraktować jako rozwinięcie zdania pojawiającego się w końcowej części wiersza: „innego nie ma świata". Ten antyplatoński pogląd jest zarazem apologią nietzscheanizmu. Historia braci, którzy uwierzyli w sny i zakochali się w głosie dobiegającym zza muru, pokazuje, że nie ma innego świat niż ten, w którym żyjemy. Czym jednak jest ten świat - wcale nie jest takie oczywiste. Czytamy przecież:

Dwunastu braci, wierząc w sny, zbadało mur od marzeń strony,

A poza murem płakał głos, dziewczęcy głos zaprzepaszczony. (s. 176)

Bracia żyją w świecie snów, znajdują się po stronie muru „od marzeń strony"! Przyjmowana dotychczas przez interpretatorów teza, że bohaterowie znajdują się w „rzeczywistym” świecie, jest zasadna tylko wtedy, jeśli przyjmiemy nietzscheańskie stanowisko, że i on jest wytworem złudnych zmysłów, marzeń i opowieści („I znikła treść - i znikną ślad - i powieść o nich już skończona!" - podsumowana zostaje śmierć cieni dwunastu braci). Świat jest iluzją pragnącej świadomości. Wówczas wiersz Dziewczyna można byłoby czytać jako jedną z bardziej pesymistycznych diagnoz ludzkiej kondycji: oprócz potężnej woli życia nie ma nic trwałego. Lecz nawet wola życia nie jest tu, jak u Schopenhauera, nieśmiertelna. Kiedy bowiem młoty niszczą mur, demaskując „kłamliwość snów” tworzących złudzenie innego świata, kończą swą pracę i zamierają: nic więcej się nie dzieje. Nie istnieje żaden ,inny świat”, jest tylko nicość, próżnia nieba i „zgroza nagłych cisz”. Cały wiersz można by nawet, choć z dużą ostrożnością, potraktować jako poetycką transpozycję Zmierzchu bożyszcz Nietzschego. Dziełko filozofa nosi wszak podtytuł: jak filozofuje się mtotem ${ }^{39}$.

39 Nawiązania widać tu zarówno w sferze ideowej: jawny antyplatonizm zostaje wzmocniony tezą o fikcyjności dostępnego nam świata, jak i na poziomie zbieżności motywów („filozofowanie młotem”) oraz tematów. Nietzsche w rozdziale Jak „świat prawdziwy” stat się w końcu bajka rekonstruuje sześć etapów historii odchodzenia od błędnych założeń platonizmu: 1. Świat prawdziwy, w którym żyje mędrzec. 2. Świat prawdziwy, do którego mędrzec dąży. Tutaj też Nietzsche pisze o idei, która staje się „subtelniejsza, bardziej dwuznaczna, bardziej nieuchwytna - staje się kobietą, staje się chrześcijańska...”. 3. Świat prawdziwy, nieosiągalny, niedający się udowodnić, obiecać, ale stanowiący pocieszenie, zobowiązanie, imperatyw. 4. Świat prawdziwy nieosiągalny, nieznany i niezobowiązujący do niczego. 5. „Świat prawdziwy” jako zbędna idea. 6. Stan po odrzuceniu podziału na świat prawdziwy i pozorny. Ostatni etap jest dziełem filozofii Nietzschego. Wobec wskazanych zbieżności, ostatnia część Zmierzchu bożyszcz, zatytułowana Mówi mtot, w której czytamy: „Czemuście 
Niewielu badaczy zwróciło uwagę na fakt, że słowo Dziewczyna w całym wierszu pisane jest wielką literą ${ }^{40}$. Ten chwyt nie zostaje przez poetę powtórzony $\mathrm{w}$ żadnym innym utworze, a przecież dziewczyna jest bohaterką niejednego z nich. Nie należy więc interpretować tego wiersza jako utworu o dziewczynie, lecz o Dziewczynie. Skoro zatem żyjący w świecie marzeń bracia śnią o znajdującej się - wedle ich wyobrażeń - po drugiej stronie muru Dziewczynie, to życie Dziewczyny miałoby być gwarancją istnienia jakiegoś innego, prawdziwszego niż utkany ze snów i pragnień, świata. W wierszach Leśmiana jeszcze tylko jedno słowo pisane jest raz wielką, raz małą literą. To słowo bóg/ Bóg ${ }^{41}$. Czy wolno zatem przyjąć, że Dziewczyna w tym utworze nie jest istotą ludzką? Że reprezentuje rodzaj Absolutu? Jeśli Bóg staje się celem dążeń dla tego, kto weń wierzy, Dziewczyna byłaby tu rodzajem bogini świeckiej religii: staje się dla dwunastu braci obiektem pragnienia, na którym koncentrują swoje dążenie. U Nietzschego alegorią chrześcijańskiej idei „prawdziwego świata" jest wszak kobieta: istota subtelniejsza, ale też bardziej dwuznaczna i nieuchwytna. Jeśli dodamy, że według kabały (a wątki kabalistyczne przewijają się przez wiersze Leśmiana) liczba dwanaście sugeruje doskonały Boży porządek, który obejmuje wszystkich ludzi, nikogo nie pozostawiając na zewnątrz ${ }^{42}$, można by potraktować wiersz Dziewczyna jako parodiam sacra, w której pragnienie Boga zostaje zastąpione pragnieniem Dziewczyny - jako idei prawdziwego świata.

tacy miękcy? O, moi bracia, pytam was zatem: czyż nie jesteście - moimi braćmi?", również wydaje się nieprzypadkowo zbieżna z motywem dwunastu braci, którzy pragnęli rozbić mur, by dotrzeć do innego świata. Bohaterowie wiersza Leśmiana zdają się wcielać w czyn zalecenie Nietzschego: „bądźcie twardzi!”. F. Nietzsche, Zmierzch bożyszcz czyli jak filozofuje się młotem, przekł., oprac., posłowie P. Pieniążek, Kraków 2006.

$4^{\circ}$ O roli wielkiej litery w słowie Dziewczyna pisał K. Wyka (op.cit., s. 216), który uznał, że pisownia ta sugeruje, iż chodzi tu nie o konkretną dziewczynę, lecz o dziewczynę w ogóle. Wspomina też o tym A. Izdebska, która w swojej interpretacji wiersza idzie tropem Wyki (zob. O „Dziewczynie”, w: Poezje Bolestawa Leśmiana. Interpretacje, red. B. Stelmaszczyk, T. Cieślak, Kraków 2000, s. 37-38).

${ }^{4} \mathrm{O}$ złożonych i niejednorodnych koncepcjach Boga w poezji Leśmiana obszernie pisze C. Rowiński, op.cit. (zob. rozdz. Człowiek i Bóg). Według autora poeta stosuje wielką literę tam, gdzie myśli o Bogu prawdziwym, pisząc zaś o bogu fałszywym, stosuje małą literę.

$4^{2}$ I tak mamy dwanaście pokoleń Izraela oraz dwunastu Apostołów. W Apokalipsie liczba wybranych do zbawienia opiera się na tej właśnie liczbie (Ap 7), a końcowa liczba, będąca iloczynem dwanaście, dwanaście i tysiąc, co daje 144000 wybranych, oznacza, że w zamyśle Bożym zbawieni mają być wszyscy ludzie (Ap 14,1). Dwanaście jest również liczbą „konstruktywną” w opisie Nowego Jeruzalem (Ap 21). 
Leśmian wielokrotnie mierzy się w swej poezji z Nietzscheańską śmiercią Boga. Wiersz Dziewczyna opowiada o tym, że człowiek nie może żyć bez celu, bez Lacanowskiego wyobrażonego obiektu pragnień, lub - mówiąc językiem Lévinasa - bez wiary w Upragnione. W świecie bez Boga człowiekowi tym bardziej potrzebne są marzenia i sny, musi mieć cel, aby doń dążyć, to bowiem nadaje jego życiu sens. Dziewczyna - utopijny obiekt, staje się w tym wierszu symbolem nieosiągalnego celu, do którego zmierzają wszyscy Leśmianowscy bohaterowie. Po rozbiciu muru przez młoty - twardsze od ludzi, po nietzscheańsku zdolne zatem do rozbicia iluzji jakichś innych, prawdziwszych światów - docieramy do miejsca, w którym Nietzsche ogłasza swoje przesłanie: jesteśmy zawieszeni w próżni, w świecie zmyślenia i pozorów, za którymi nic się nie kryje.

Czytając zatem wiersz Dziewczyna w duchu negatywnej hermeneutyki, można zgodzić się z interpretacją Markowskiego, który dostrzega $\mathrm{w}$ nim autotematyczny wykład o naturze literatury, choć zarazem budzi ona pewne wątpliwości. $Z$ jednej strony - $\mathrm{w}$ świetle poczynionych uwag wydaje się zbyt optymistyczna. Zakłada bowiem, że jeśli literatura jest fikcją, to świat, w którym żyjemy, jest prawdziwy. Z drugiej zaś strony - jednoznaczność wniosków na temat roli słowa poetyckiego, które „podszyte jest nicością”, domaga się weryfikacji po skonfrontowaniu $\mathrm{z}$ całym dorobkiem Leśmiana oraz $\mathrm{z}$ jego poglądami na temat poezji.

Ten późny, pesymistyczny wiersz obrazuje zatem punkt dojścia filozofii Leśmiana, nie stanowi jednak ostatecznej odpowiedzi na epistemologiczne i ontologiczne pytania tej poezji: jest tylko jedną $\mathrm{z}$ wielu rozpatrywanych przez Leśmiana cząstkowych prób zmierzenia się z pytaniami o cel, do którego zmierza człowiek.

U podłoża Leśmianowskiej figury pragnienia odnajdujemy zatem filozofię życia, aktywizm, schopenhaueryzm, dionizyjskość zaczerpniętą z nietzscheanizmu, lecz zarazem jest to filozofia podszyta pesymizmem dużo głębszym niż pesymizm Schopenhauera. U tego ostatniego człowiek znajdował bowiem ukojenie w sztuce, w estetycznej kontemplacji piękna, przenoszącej go w świat wiecznych idei, tymczasem w antyplatońskiej filozofii Leśmiana piękno nie odsyła do rzeczywistości innej niż świat bytów, jest równie jak one nietrwałe i tymczasowe. Obcowanie z nim nie uśmierza bólu, lecz jeszcze go potęguje, podmiot świadom jest bowiem swojej czasowości i przemijalności każdego doświadczenia. Pragnienia krążą u niego w zamkniętym obiegu, są nierozłączne, ujawniają się na różnych poziomach, nigdy jed- 
nak nie otwierają perspektywy transcendencji rozumianej jako „przejście poza”, przekroczenie rzeczywistości i osiągnięcie nowego poziomu ludzkich doświadczeń i zmysłów. Świat Leśmiana jest bowiem niedualistyczny - nie istnieje w nim rozdział rzeczy od idei. Nawet Bóg jest tu częścią świata przedstawień naznaczonych brakiem i niedoskonałością - dotarcie do niego, przekroczenie granicy boskiej kreacji nie daje gwarancji osiągnięcia kresu pragnienia. Celem pragnienia okazuje się samo pragnienie.

\section{ELŻBIETA WINIECKA}

\section{Distance and the urge of directness}

The article presents B. Leśmian as a poet involved in his self-imposed task of promoting a return to primeval nature, but, at the same time, somebody who is fully aware of the utopian character of thus formulated and adopted assumptions. The two contradictory approaches converge in a poetic figure of desire. This particular urge is treated as a model of the imagination of the poet, who creates his poetical world knowing that the ultimate aim is unattainable but constitutes the ideal of poetry and can only be a state of cognitive assurance and self-knowledge or, alternatively, a situation of ontological stability and fulfilment. However, to reach this utmost goal, either on the poetical plane or on the existentialist, epistemological and ontological plane, to fulfill the cherished desires, is not possible within the poetical world created by Leśmian. The raison d'etre of the self manifested by the protagonists of his poems as well as a justification of this poetry is the very striving towards the goal. The article shows the relevant dimensions of that desire as a metapoetical figure, anthropological and existentialist figures and epistemological and ontological figures. It further presents the opposition and the inner conflict within the modern views of the poet, who, consciously inscribes into his project its impracticability. The distance towards the current times and towards the idealistic assumptions of his own poetical programme constitutes the intrinsic originality of Leśmian's poems.

ELŻBIETA WiNiECKA - dr, adiunkt w Zakładzie Literatury i Kultury Nowoczesnej Instytutu Filologii Polskiej UAM. Autorka książki Białoszeruski sylleptyczny (Poznań 2006). Publikowała m.in. w „Pamiętniku Literackim”, „Tekstach Drugich” i „Przestrzeniach Teorii” e-mail: e.winiecka@wp.pl 